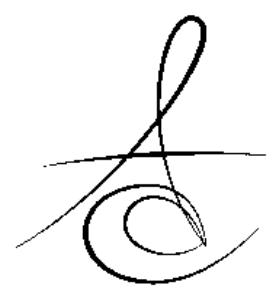

\title{
SUNRAY APPEARANCE ON SONOGRAPHY IN OSTEOSARCOMA OF THE MANDIBLE: A RARE CASE REPORT
}

\author{
MANDİBULA OSTEOSARKOMUNDA ULTRASONOGRAFİDE GÜNEŞ IŞINI \\ GÖRÜNÜMÜ: NADİR BİR OLGU SUNUMU
}

\author{
Araş.Gör. Hande SAĞLAM* \\ Araş.Gör. Fatma AKKOCA KAPLAN* \\ Doç.Dr. İbrahim Şevki BAYRAKDAR*
}

Makale Kodu/Article code: 4438

Makale Gönderilme tarihi: 15.06 .2020

Kabul Tarihi: 18.12 .2020

DOI : $10.17567 /$ ataunidfd.837517
Hande Sağlam: ORCID ID: 0000-0001-7792-5106

İbrahim Sevki Bayrakdar: ORCID ID: 0000-0001-5036-9867

Fatma Akkoca Kaplan: ORCID ID: : 0000-0002-4522-656x

\begin{abstract}
Osteosarcoma comprises $23 \%$ of head and neck malignancies. Studies show that $6 \%$ to $9 \%$ of all osteosarcomas are seen in the maxilla and mandible. In osteosarcoma in jaws, the survival rate is higher and the risk of metastasis is lower compared to osteosarcoma in the extremities. The gold standard in osteosarcoma diagnosis is computed tomography and magnetic resonance imaging. 'Sunray appearance' is a common radiologic finding of sarcomas. A 29-year-old male patient received to our clinic with pain and swelling in the right mandible. Extra-oral examination revealed that facial asymmetry and significant swelling in the right mandible. On the cone beam computerized tomography examination, a lytic, mixed lesion area was observed with conical shaped root resorption around the mandibular right second premolar and first molar tooth roots. Ultrasound examination revealed that thinning, expansion, and erosion of the buccal cortical bone and 'sunray appearance' in the mandible. Cone beam computerized tomography and ultrasound have become an important diagnostic technique for the evaluation of maxillofacial pathologies. Ultrasound imaging is a rapid technique that aids in the early and differential diagnosis of pathologies. Sunray appearance is a pathognomic finding for osteosarcoma. In present case report, diagnostic ultrasonography is the second case in the literature used in osteosarcoma of the mandible.
\end{abstract}

Keywords: Cone beam computed tomography, jaw osteosarcoma, sunray, ultrasonography

öz

Osteosarkom, baş ve boyun malignitelerinin \%23'ünü oluşturur. Çalışmalar, tüm osteosarkomların \%6 ila \%9'unun maksilla ve mandibulada görüldüğünü göstermektedir. Çenelerde görülen osteosarkomda sağkalım oranı daha yüksektir ve metastaz riski ekstremitelerde görülen osteosarkom ile karşılaştııılığında daha düşüktür. Osteosarkom tanısında altın standart bilgisayarlı tomografi ve manyetik rezonans görüntülemedir. Radyografik olarak, "güneş ışını görünümü" sarkomların yaygın bir bulgusudur. 29 yaşında erkek hasta kliniğimize sağ mandibulada ağrı ve şişlik ile başvurdu. Ekstraoral muayenede, yüz asimetrisi ve sağ mandibular çenede belirgin şişlik gözlendi. Konik ışını bilgisayarlı tomografi incelemesinde, mandibular sağ ikinci premolar ve birinci molar diş kökleri çevresinde konik şekilli kök rezorpsiyonu ile litik, karışık bir lezyon alanı gözlenmiştir. Ultrasonografide ise, mandibulada bukkal korteksin kemik incelmesi, erozyonu ve "güneş ışını görünümü" gözlenmiştir. Konik ışınlı bilgisayarlı tomografi ve ultrasonografi, maksillofasiyal patolojilerin değerlendirilmesi için önemli bir tanı tekniği haline gelmiştir. Ultrasonografi, patolojilerin erken ve ayıııc tanısına yardımcı olan hızlı bir tekniktir. Güneş ışını görünümü osteosarkom için patognomik bir bulgudur. Sunduğumuz olgu; mandibula osteosarkomunun tanısında ultrasonografi kullanılan literatürdeki ikinci olgudur.

Anahtar Kelimeler: Çene osteosarkomu, güneş ışını, konik ışınlı bilgisayarlı tomografi, ultrasonografi

\section{*Eskisehir Osmangazi University, Faculty of Dentistry, Department of Dento-Maxillofacial Radiology, Eskisehir}

Kaynakça Bilgisi: Sağlam H, Akkoca Kaplan F, Bayrakdar Ş. Mandibula osteosarkomunda ultrasonografide güneş ışını görünümü: nadir bir olgu sunumu. Atatürk Üniv Diş Hek Fak Derg 2021; 31: 433-43.

Citation Information: Saglam H, Akkoca Kaplan F, Bayrakdar S. Sunray appearance on sonography in osteosarcoma of the mandible: a rare case report. $J$ Dent Fac Atatürk Uni 2021; 31: 433-43.

\section{INTRODUCTION}

Osteosarcoma is the most common primary sarcoma of bone, and these tumor cells consist of bone and osteoid tissue. ${ }^{1,2}$ Several studies in the literature have reported cases of osteosarcoma in the jaws. $^{3-7}$ Osteosarcoma comprises $23 \%$ of head and neck malignancies. Studies show that $6 \%$ to $9 \%$ of all osteosarcomas are seen in the maxilla and mandible. ${ }^{8,9}$ Both jaws are affected equally and they 
are observed more frequently in the posterior of the jaws. ${ }^{10}$ In osteosarcoma in jaws, the survival rate is higher and the risk of metastasis is lower compared to osteosarcoma in the extremities. ${ }^{7}$ In a study; the proliferation index of tumor cells in osteosarcoma cases in jaws was compared with osteosarcoma cases in long bones. It has been found that tumor cells in osteosarcoma cases in jaws have a lower proliferation fraction. ${ }^{11}$

The exact cause of osteosarcoma is unknown and there are many risk factors. Rapid bone growth and increasing incidence during adolescent growth are considered an important predisposing factor. ${ }^{3}$ Gender is a controversial issue in jaw osteosarcoma, but its incidence in male has often been reported more frequent. 12,13

The gold standard in diagnosis of osteosarcoma is computed tomography (CT) and magnetic resonance imaging (MRI). ${ }^{14}$ Various information about the tumors is obtained in methods such as CT and MRI. These imaging modalities show tumor calcification, invasion of adjacent tissues, staging and the presence of intramedullary or extramedullary involvement. In addition, evaluation of pterygopalatine fossa, infratemporal fossa and cranial cavity is made. However, the radiation dose is high. ${ }^{15} \mathrm{MRI}$ is excellent in showing soft tissue pathologies of the tumor. Nevertheless, due to its high cost, its accessibility is low. These methods are primarily used for the diagnosis and staging of osteosarcoma. ${ }^{14}$

Depending on the developments in medical technologies, computed tomography with lower doses was produced for use in dental radiology. ${ }^{16,17}$ Cone beam computed tomography (CBCT) is a commonly utilized imaging method in dentistry, reconstructing the craniofacial structure as three dimensions. ${ }^{18,19}$ CBCT imaging is an accepted method of radiographic evaluation of head and neck pathologies due to low radiation dose and ease of use. ${ }^{20}$

Ultrasonography (US) provides simultaneous image using sound waves spread and reflection. The first use of US to dentistry was notify by Lefkowitz in 1953. Until now; US has been used to determine soft tissue pathologies, maxillofacial fractures, periodontal bone loss, temporomandibular diseases, and to measure muscle and soft tissue thickness. It has important advantages including free of ionizing radiation, being non-invasive, easy to use, painless, reproducible, and simultaneous display. ${ }^{21}$ Diagnostic US is widely used for the evaluation of pathologies, lymph nodes, vascular pathological conditions and floor of the mouth in the salivary glands. It is also used during fine needle aspiration. ${ }^{21} 14$

Radiographically, 'sunray appearance' is a common finding of sarcomas ${ }^{22}$ 'Sunray appearance'; It can be expressed in terms of, 'sunburn' and 'spicule'. These terms refer to the situation where the new bone forms vertically to the cortex and results in multiple lines. The occurrence of this condition is caused by the rapid removal of the periosteum from the cortex. There are many substances that trigger the formation of new bone by contacting the inner surface of the periosteum. These substances contain inflammatory products, blood, granulomatous response, and neoplasms. ${ }^{22}$ The aim of this study is to present the 'sunray appearance' of mandible osteosarcoma in US and CBCT.

\section{CASE REPORT}

A 29-year-old male patient admitted to our clinic with pain and swelling in the right mandible. Informed consent was obtained from the patient. The patient does not have any disease in his medical history. In the extraoral examination, facial asymmetry and significant swelling in the right mandible were observed (Figure 1). In the intraoral examination of the patient, swelling and erythema were observed in the buccal mucosa of related area. Panoramic radiography showed a lytic lesion area with resorption in the roots of teeth mandibular right second premolar and first molar (Figure 2). Vital response was not obtained in mandibular right first molar and second premolar teeth on the vitalometer test.

In the CBCT (Planmeca Promax 3D Mid, Helsinki, Finland) examination, a lytic, mixed lesion area was observed with conical shaped root resorption around the mandibular right first and second molar tooth roots. Erosion in the buccal and lingual cortical bone, the periosteal reaction in the buccal cortical bone attracted the attention. Sunray appearance was observed in axial and coronal sections. (Figure 3).

On the US (Mindray DC N3 device, Shenzhen, China) examination observed bone thinning, expansion, and erosion of the buccal cortex, with bone spicules at $90^{\circ}$ to the bone surface (sunray appearance) in the mandible. In our case, "sunray appearance" was detected by US with buccal cortical bone erosion and expansion. (Figure 4). 
Osteosarcoma was diagnosed as a result of incisional biopsy taken from the patient. Patient was consulted to the department of Otolaryngology for the treatment and follow up.

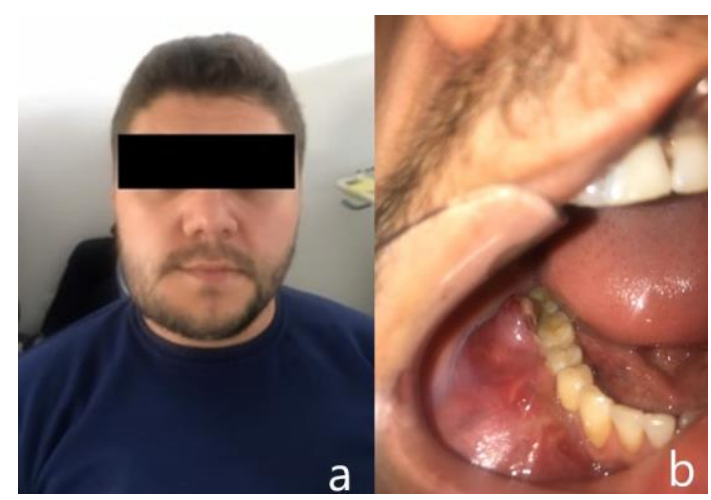

Figure1. Clinical findings of patient a: Facial asymmetry and swelling in the right mandible in the extraoral appearance of a 29-year-old male patient. b: Swelling, ulceration and erythema in the right mandible in the intraoral appearance of a 29-year-old male patient.

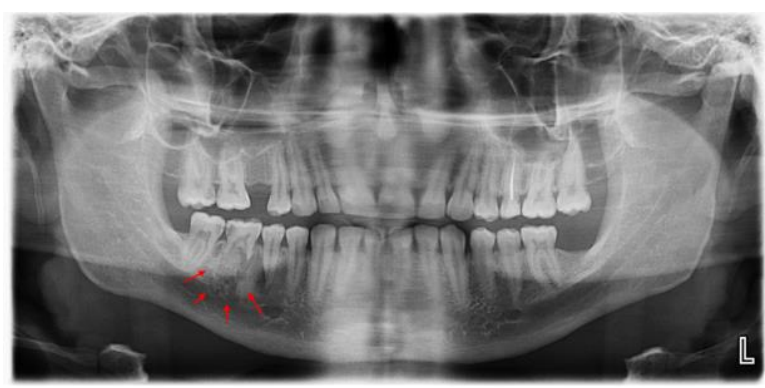

Figure 2. Panoramic radiography showed a lytic lesion area with resorption in the roots of teeth mandibular right first molar and second premolar.

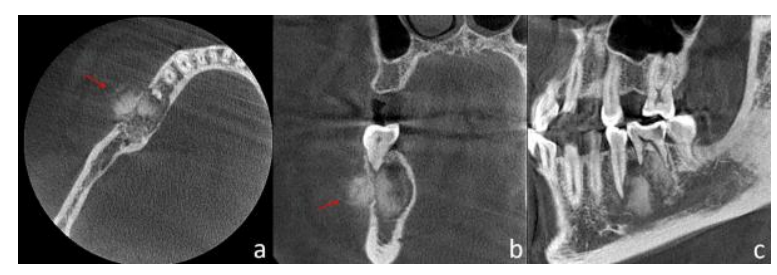

Figure 3. $C B C T$ finding of lesion a: Axial slice of $C B C T$ image shows mixt lesion area with buccal cortical perforation and "sunray appearance" periosteal reaction. b: Coronal slice of CBCT image shows mixt lesion area with buccal cortical perforation and 'sunray appearance' periosteal reaction. c: Sagittal slice of CBCT image shows a lytic, mixed lesion area with conical shaped root resorption around the mandibular right first molar and second premolar tooth roots.

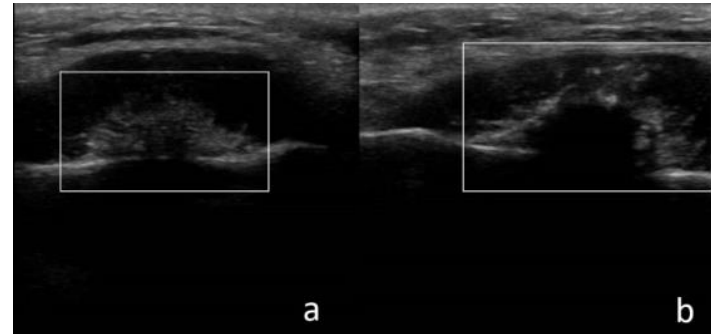

Figure 4. $(a, b)$ : The sunray appearance of mandible osteosarcoma on the ultrasound.

\section{DISCUSSION}

Osteosarcoma is a malignant tumor described by the formation of bone or osteoid tissue by tumor cells. Osteosarcoma is the most widespread primary malignant bone tumor after multiple myeloma. ${ }^{7}$ The exact cause of osteosarcoma is unknown and there are many risk factors. Rapid bone growth and increasing incidence during adolescent growth were considered as an important predisposing factor. ${ }^{3}$ In addition, genetic predisposition has been monitorized in patients with the mutated p53 tumor suppressor and retinoblastoma gene. Osteosarcoma has been found to be secondary to benign bone lesions such as Paget's disease and fibrous dysplasia in elderly patients. ${ }^{15,23}$

In several studies, cases of jaw osteosarcoma have been reported in the literature. These studies have shown in osteosarcoma of the jaw compared to osteosarcoma of extremities increased five-year survival rate and lower incidence of metastasis. ${ }^{3-5}$ However, the causes of this situation are still controversial. $^{7}$

In the second decade, primary osteosarcoma peaks. $^{24}$ Jaw osteosarcoma occurs in a larger age group between the third and fourth decade. ${ }^{3}$ According to Garrington ${ }^{15}$, the average age of osteosarcoma of the jaw ranges from 34 to $36.1^{15}$ The present patient in our case report was 29 years old.

Gender is a controversial issue in osteosarcoma of the jaw. In their 2001 study, Mardinger et al 13 found that the male to female incidence rate is $1.2 / 1$. In another study, August et al. ${ }^{12}$ found the incidence ratio of male: female $1.1 / 1$. They thought this was due to the long skeletal growth and additional bone volume in male. ${ }^{15}$ Our case in this study was also a male patient. There are studies indicating that the incidence of jaw osteosarcoma is equal in the mandible and maxilla.,12,25 However, higher 
prevalence has been reported in the maxilla with few studies. ${ }^{15,26}$ In present case, osteosarcoma was detected in the mandible.

The characteristic clinical finding in primary osteosarcoma is bone pain during activity. However, pain is not a significant character in jaw lesions and swelling is the most common reason for application. ${ }^{3,15,25}$ In present patient had complaints of both pain and swelling.

The radiographic appearance of osteosarcoma can be osteolytic, osteogenic, or mixed. Bone spicules perpendicular to the lesion surface can be observed in the periosteum. This is called the 'sunray appearance' .${ }^{15}$ Since the tumor develops very rapidly, a 'sunray appearance' occurs, which is a pathognomic finding for osteosarcoma. ${ }^{14}$ It is often difficult to interpret the radiographic appearance of osteosarcoma. 26 In present case, the sunray appearance was induced by malignant periosteal new bone formation.

Mittal et al. ${ }^{22}$ reported the 'sunray appearance' of the clavicle Ewing sarcoma with US. $\mathrm{Ng}$, et al. ${ }^{14}$ presented a first report of the ultrasound features of osteosarcoma of the mandible. In their case report, they reported the 'sunray appearance' of osteosarcoma with the US. In present this study, diagnostic US is the second case in the literature used in osteosarcoma of the mandible. US shows bone surface and contour rather than intraosseous bone. ${ }^{14}$ In present case, erosion, expansion and most importantly, 'sunray image' in the buccal cortex was detected with US in the mandibula. Apart from this, the peripheral edge of the tumor can be evaluated with US. In addition, fine needle aspiration biopsy can be performed. ${ }^{18}$

Although jaw osteosarcoma is rare, it should be considered as a differential diagnosis in the diagnosis of tumoral pathologies in the maxilla and mandible. Advanced radiological imaging techniques should be used in patients with suspected malignancy in twodimensional radiographs such as panoramic and periapical. CBCT and US have become an important diagnostic technique for evaluation of maxillofacial pathologies. US imaging is a rapid technique that aids in the early and differential diagnosis of pathologies. Sunray appearance is a pathognomic finding for osteosarcoma, and this rare finding was presented in our study. This study demonstrates the importance of performing a US scan in patients with swelling and when we suspect malignancy. It is one of the methods that clinicians can use for initial evaluation.
Declarations

All procedures followed were in accordance with the ethical standards of the responsible committee on human experimentation (institutional and national) and with the Helsinki Declaration of 1975, as revised in 2008 (5). Informed consent was obtained from all patients for being included in the study

Conflict of interest

The authors, Hande Sağlam, Fatma Akkoca Kaplan, İbrahim Şevki Bayrakdar declare that they have no conflict of interest.

Funding

Neither the authors nor your institution received payment or services from a third party for any aspect of the submitted work.

\section{REFERENCES}

1. Lin PP, Patel S. Osteosarcoma. In: Bone Sarcoma. Springer; 2013:75-97.

2. Kocasaraç HD. Osteosarkom, Kondrosarkom, Ewing Sarkomu. Türkiye Klinikleri Ağız Diş ve Çene Radyolojisi-Özel Konular 2017;3:64-9.

3. Garrington GE, Scofield HH, Cornyn J, Hooker SP. Osteosarcoma of the jaws. Analysis of 56 cases. Cancer 1967;20:377-91.

4. Caron AS, Hajdu SI, Strong EW. Osteogenic sarcoma of the facial and cranial bones: A review of fortythree cases. Am J Surg 1971;122:719-25.

5. Russ JE, Jesse RH. Management of osteosarcoma of the maxilla and mandible. Am J Surg 1980;140:5726.

6. Sanroman JF, del Hoyo JA, Diaz F, et al. Sarcomas of the head and neck. Br J Oral Maxillofac Surg 1992; 30:115-8.

7. Slootweg PJ, Müller $\mathrm{H}$. Osteosarcoma of the jaw bones Analysis of 18 cases. J maxillofac Surg 1985; 13:158-66.

8. Nthumba PM. Osteosarcoma of the jaws: a review of literature and a case report on synchronous multicentric osteosarcomas. World J Surg Oncolog 2012; 10:240.

9. Delgado R, Maafs E, Alfeiran A, et al. Osteosarcoma of the jaw. Head \& neck. 1994;16(3):246-252.

10. SÜMER AP, ÇALIŞKAN A. Çene Kemiklerinde İzlenen Osteosarkom. Türkiye Klinikleri Ağız Diş ve Çene Radyolojisi-Özel Konular 2015;1:10-6.

11. Sengüven DB, Gültekin SE, Uluoğlu Ö. Çene Osteosarkomlarında Proliferasyon İndeksinin Değerlendirilmesi. Atatürk Üniv Diş Hek Fak Derg 23:75-81.

12. August M, Magennis P, Dewitt D. Osteogenic sarcoma of the jaws: factors influencing prognosis. Int J Oral Maxillof Surg 1997; 26:198-204.

13. Mardinger O, Givol N, Talmi YP, Taicher S. Osteosarcoma of the jaw: the Chaim Sheba Medical 
Center experience. Oral Surg Oral Med Oral Pathol Oral Radiol Endod 2001;91:445-51.

14. Ng SY, Songra A, Ali N, Carter JLB. Ultrasound features of osteosarcoma of the mandible-a first report. Oral Surg Oral Med Oral Pathol Oral Radiol Endodontol 2001;92:582-6.

15. Nissanka E, Amaratunge E, Tilakaratne W. Clinicopathological analysis of osteosarcoma of jaw bones. Oral Diseas 2007;13:82-7.

16. White SC, Pharoah MJ. The evolution and application of dental maxillofacial imaging modalities. Dent Clin North Am 2008;52:689-705.

17. Scarfe WC, Farman AG, Sukovic P. Clinical applications of cone-beam computed tomography in dental practice. J Canadian Dent Assoc 2006;72:75.

18. Mozzo P, Procacci C, Tacconi A, Martini PT, Andreis IB. A new volumetric CT machine for dental imaging based on the cone-beam technique: preliminary results. Eur Radiol 1998;8:1558-64.

19. Akarslan Z, Peker İ. Bir diş hekimliği fakültesindeki konik ışınlı bilgisayarlı tomografi incelemesi istenme nedenleri. Acta Odont Turcica 2015;32:1-6.

20. Yeung AWK, Tanaka R, Khong P-L, von Arx T, Bornstein MM. Frequency, location, and association with dental pathology of mucous retention cysts in the maxillary sinus. A radiographic study using cone beam computed tomography (CBCT). Clin Oral Inves 2018; 22:1175-83.

21. Kocasarac HD, Angelopoulos C. Ultrasound in dentistry: toward a future of radiation-free imaging. Dent Clin 2018;62:481-9.

22. Mittal A, Mehta V, Bagga $P$, Pawar I. Sunray appearance on sonography in Ewing sarcoma of the clavicle. J Ultrasound Med 2010; 29:493-5.

23. Kleer CG, Unni KK, McLeod RA. Epithelioid hemangioendothelioma of bone. Am J Surg Pathol 1996; 20: 1301-11.

24. Forteza G, Colmenero B, Lopez-Barea F. Osteogenic sarcoma of the maxilla and mandible. Oral Surg Oral Med Oral Pathol 1986;62:179-84.

25. Klaassen M, Hoffman G. Ewing sarcoma presenting as spondylolisthesis. Report of a case. JBJS 1987; 69:1089-92.

26. Clark JL, Unni KK, Dahlin DC, Devine KD. Osteosarcoma of the jaw. Cancer. 1983;51: 2311-6.

\section{Sorumlu Yazarın Yazışma Adresi} Hande SAĞLAM

Eskisehir Osmangazi University, Faculty of Dentistry, Department of Dentomaxillofacial Radiology, Eskisehir-Turkey

TLF: 00902222391303

Fax number: 00902222391273

E-mail address: hande_hegs@hotmail.com

Orcid number: 0000-0001-7792-5106 